\title{
New records of Chewing Lice (Phthiraptera) From Some Bird Species
} in Turkey

Türkiye’deki Bazı Kuş Türlerinden Yeni Çiğneyici Bit (Phthiraptera) Türü Kayıtları

\author{
Bilal DiK
}

Department of Parasitology, Faculty of Veterinary Medicine, Selçuk University, Konya, Turkey

\begin{abstract}
Objective: This study was carried out to detect chewing-lice found on some birds in Turkey. Methods: For this aim, a Eurasian collared dove (Streptopelia decaocto), a budgerigar (Melopsittacus undulatus) and a marbled duck (Marmaronetta angustirostris) were examined for the louse.

Results: Columbicola bacillus (Giebel, 1866) was found on a Eurasian collared dove (Streptopelia decaocto), Afrimenopon waar (Eichler, 1947) on a budgerigar (Melopsittacus undulatus) and Anatoecus icterodes (Nitzsch, 1818) on a marbled duck (Marmaronetta angustirostris). Conclusion: All three louse species were recorded for the first time in Turkey. Anatoecus icterodes was reported for the first time from marbled duck in the worldwide. Therefore, marbled duck is a new host for Anatoecus icterodes. (Turkiye Parazitol Derg 2010; 34: 168-73)
\end{abstract}

Key Words: Phthiraptera, Columbicola columbae, Afrimenopon waar, Anatoecus icterodes, Turkey

Received: 26.05.2010

Accepted: 17.08 .2010

\section{ÖZET}

Amaç: Bu araştırma bazı kuşlarda bulunan bit türlerini belirlemek için yapılmıştır.

Yöntemler: Bu amaçla bir adet Kumru (Streptopelia decaocto), bir adet Muhabbet Kuşu (Melopsittacus undulatus) ve bir adet Yaz Ördeği (Marmaronetta angustirostris) bit yönünden incelenmiş̧ir.

Bulgular: Kumru (Streptopelia decaocto)'da Columbicola bacillus (Giebel, 1866), Muhabbet Kuşu (Melopsittacus undulatus)'nda Afrimenopon waar (Eichler, 1947) Yaz Ördeği (Marmaronetta angustirostris)'nde ise Anatoecus icterodes (Nitzsch, 1818)'e rastlanmıştır.

Sonuç: Bu türlerin üçü de Türkiye'den ilk kez bildirilmiş, Anatoecus icterodes ise yaz ördeğinden dünyada ilk kez rapor edilmiştir. (Turkiye Parazitol Derg 2010; 34: 168-73)

Anahtar Sözcükler: Phthiraptera, Columbicola bacillus, Afrimenopon waar, Anatoecus icterodes, Türkiye Geliş Tarihi: 26.05.2010 Kabul Tarihi: 17.08.2010

\section{INTRODUCTION}

Only a few studies have been conducted on the Phthiraptera fauna of birds in Turkey (1-19). Because of this, the number of louse species recorded from birds in Turkey is limited. Three budgerigars had been examined for the louse up to this study (5), but no louse specimen was found on the birds. On the other hand, there was no study related to louse species occurring on Eurasian collared dove and marbled duck in Turkey. This study was carried out to detect the louse species of these birds.

\section{MATERIALS AND METHODS}

One marbled duck (Marmaronetta angustirostris), one Eurasian collared dove (Streptopelia decaocto) and one budgerigar (Melopsittacus undulatus) were examined for the louse. The marbled duck was killed by a car collision. The Eurasian collared dove and budgerigar, which were brought for treatment to the Veterinary Faculty of Selcuk University, were found to be infested with louse. Two lice specimens from the marbled duck, one from the dove and four from the budgerigar were collected. They were pre-

This paper presented as a poster presentation in Fourth International Conference of Phthiraptera (ICP4, June 13-18, 2010, Ürgüp, Turkey) Address for Correspondence/Yazışma Adresi: Dr. Bilal Dik, Selçuk Üniversitesi Veteriner Fakültesi, Parazitoloji Anabilim Dalı, Konya, Turkey Phone: +90332 2232736 Fax: +90332 2410063 E-mail: bdik@selcuk.edu.tr doi:10.5152/tpd.2010.06 
served in $70 \%$ alcohol, cleared in $\mathrm{KOH} \mathrm{10 \% ,} \mathrm{washed} \mathrm{with} \mathrm{dis-}$ tilled water and stored in alcohol series 70\%, 80\%, 90\% and $99 \%$ in four consecutive days, respectively. They were mounted on slides in Canada balsam and examined by a light microscope.

\section{RESULTS}

The lice specimens were identified as Anatoecus icterodes (Nitzsch, 1818) from the marbled duck, Columbicola bacillus (Giebel, 1866) from the Eurasian collared dove and Afrimenopon waar (Eichler, 1947) from thebudgerigar. All three species as well as the genera Anatoecus and Afrimenopon were recorded for the first time for the Phthiraptera fauna of Turkey. In addition, Anatoecus icterodes was recorded on a marbled duck for the first time.

Anatoecus icterodes (Nitzsch, 1818)

Material examined: 1 ? 10

Female: The head is sub-conical, slightly more broad than long, the preocular region is narrowed, temples very wide. The hyaline membrane is concave anteriorly; dorsal anterior plate is glassshaped, wide and shallow anterior is narrowed medially, relatively long, slender and rounded posteriorly. The trabecula is oval proximallly; antenna have five segments, the first segment is wider and the second longer than the others. Temple has one long seta and four spines; occipital bands are parallel; gular plate is sub-pentagonal (Fig. 1).

Prothorax is quadrangular, slightly broad posteriorly, longer than wide. Pterothorax is prominent laterally; convex posteriorly, and the posterolateral margin has one spin-like seta and 6 long setae on each side.

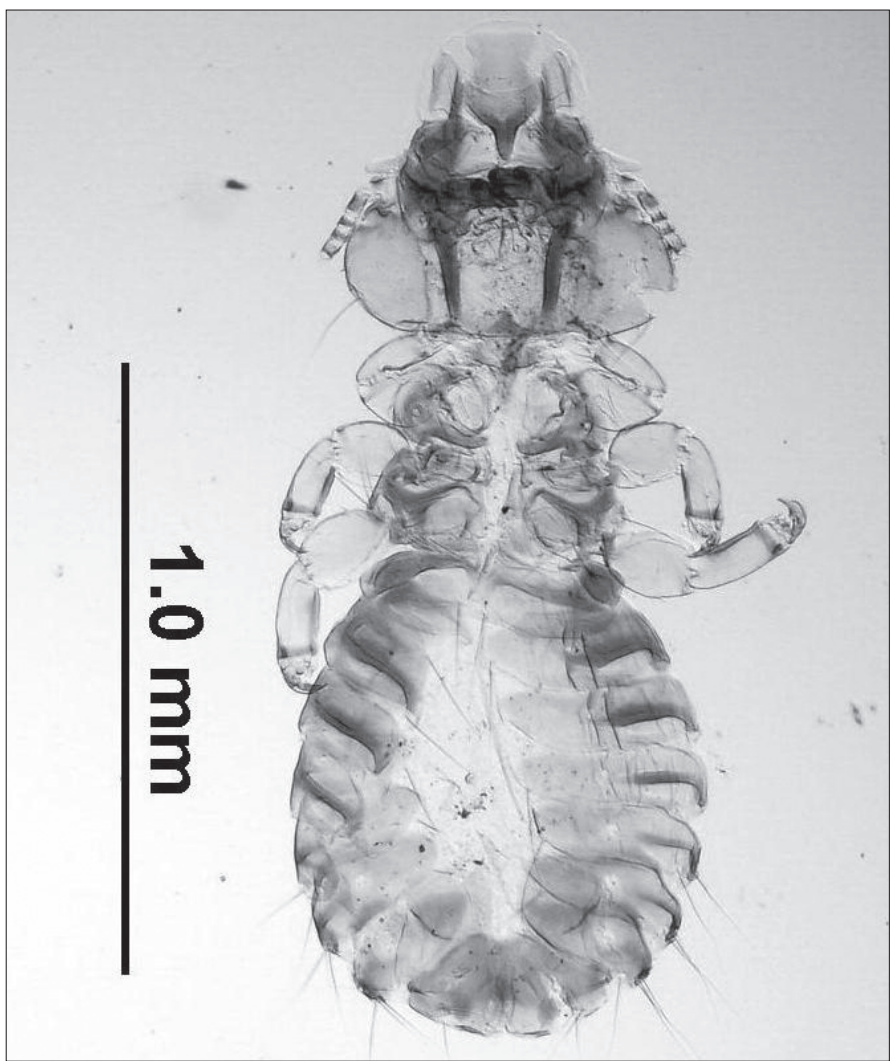

Figure 1. Anatoecus icterodes, female in ventral view, original
Abdomen is short, broad and rounded, slightly wider than the head. Paratergal plates are chitinized well. Segment I is well developed and notched anteromedially. Segments I-VII have one long seta in the posteroventral margin on each side. Lateral sides of segments VI-VIII have two long setae. Segment IX has two long and one short seta on the posterior margin. There are two clusters composed of two setae each, one short and one long.

Male: Similar to the female, but is slightly shorter. Abdominal tergites II-V are divided medially (Fig. 2). Genitalia: Basal plate is short and broad, parameres are relatively longer and enclosed proximally, penis is short. There is a well-developed horizontal band, curved posteriorly on each side. There is a vase-shaped pigmented area, oval, well-developed, concave anteriorly, edges extend to the anterior of segment $\mathrm{Vl}$.

Some measurements of Anatoecus icterodes were given in Table 1.

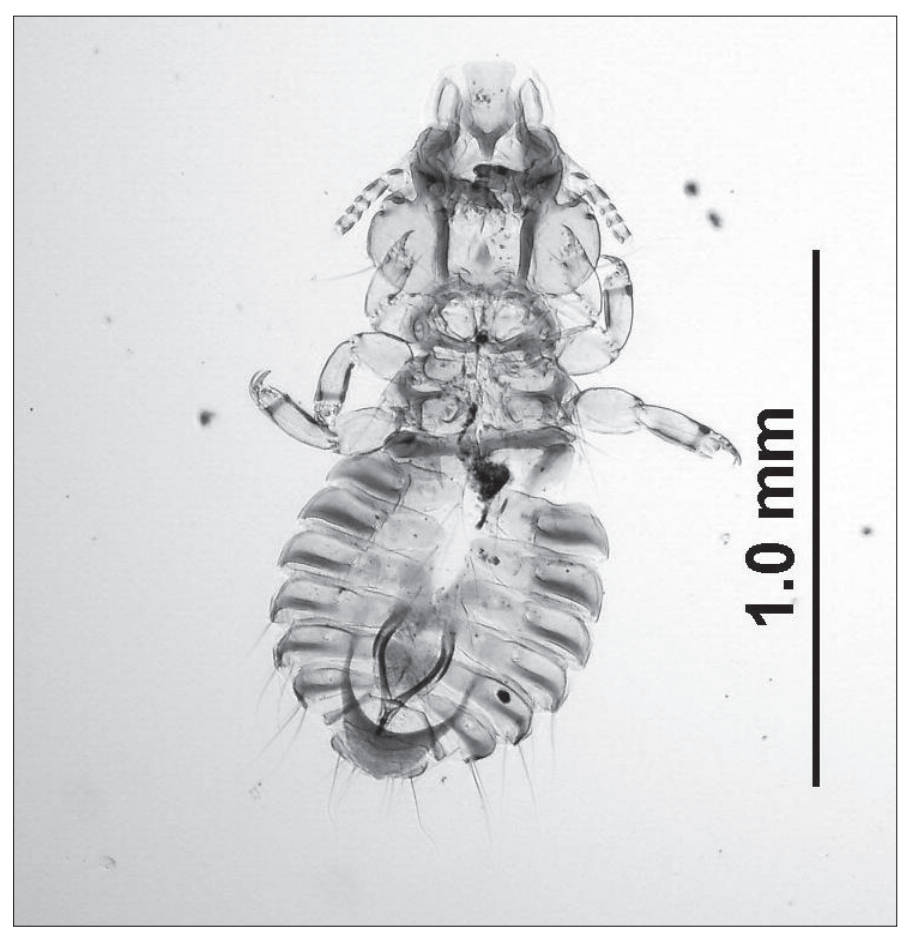

Figure 2. Anatoecus icterodes, male in ventral view, original

Table 1. Some dimensions of Anatoecus icterodes (in $\mathrm{mm}$ except HI)

\begin{tabular}{|l|c|c|}
\hline & Female (n: 1) & Male (n: 1) \\
\hline $\mathrm{HL}$ & 0.53 & 0.47 \\
\hline $\mathrm{HW}$ & 0.55 & 0.44 \\
\hline $\mathrm{HI}$ & 0.95 & 1.08 \\
\hline $\mathrm{TL}$ & 0.37 & 0.35 \\
\hline $\mathrm{TW}$ & 0.44 & 0.38 \\
\hline $\mathrm{AL}$ & 0.81 & 0.68 \\
\hline $\mathrm{AW}$ & 0.69 & 0.61 \\
\hline Tot L & 1.68 & 1.40 \\
\hline $\begin{array}{l}\text { Abbreviations for measurements are: HL: Head Length; HW: Head Width in tem- } \\
\text { ples; HI: Head Index; TL: Thoracic Length; TW: Thoracic Width; AL: Abdominal } \\
\text { Length; AW: Abdominal Width; Tot L: Total Length }\end{array}$ \\
\hline
\end{tabular}


Afrimenopon waar (Eichler, 1947)

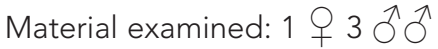

Female: Is relatively small, $1.5 \mathrm{~mm}$ (Fig. 3). Head is rounded in the anterior margin; temples rounded posteriorly; antennae are four segmented; preocular and occipital nodi moderately developed; occipital margin is slightly concave. Gular plate simple, pentagonal, narrowed anteriorly; gular plate has $4+4$ setae on each side.

Prothorax is broad anteriorly; narrowed posteriorly. Prosternal plate is weakly developed, only the posterior part is evident. Mesosternal plate is moderately long, slender and with one seta. Metastenal plate has two setae.

Abdomen is 1,5-2 times longer than the width. Abdominal sternite III has two ctenidia on each side. Segments VII-IX are weakly developed. Posterior margin is rounded. Dorsal anal fringe possess 38 setae. Chaetotaxy was not examined well due to a lot of setae being broken, especially on the abdomen.

Male: Similar to, but smaller than the female, (Fig. 4). Head rounded anteriorly, three setae, one of them short and the others very long on the posterolateral margin of the head. Sitophore sclerite of hypopharynx weakly developed (Fig. 5). Six long and two short setae are on each side of the posterolateral margin of the prothorax. Posterolateral margin of the metathorax has six medium long setae on each side. Metathorax has four short setae medioanteriorly. They extend to the posterior margin of abdominal segment I. Mesosternal and metasternal plates have five or six setae. Venter of third femur has two ctenidia. Tergocentral setae as: I, 12-15; II, 14-16; III, 14-17; IV, 15-17; V, 15-18; VI, 13-14; VII, 11-14; VIII, 9-11. Genitalia: Basal apodeme narrow, parameres straight and slender, penis short, stout, rounded and slightly concave posteriorly, genital sac spinous.

Some measurements of Afrimenopon waar were given in Table 2.

Columbicola bacillus (Giebel, 1866)

Material examined: 1 q

Body is long and slender (Fig. 6). Head is very long and slender posteriorly. Dorsal anterior plate relatively narrowed and 0,147

Table 2. Some dimensions of Afrimenopon waar (in mm, except HI)

\begin{tabular}{|l|c|c|c|c|}
\hline \multirow{2}{*}{} & \multirow{2}{*}{ Female (n:1) } & \multicolumn{3}{|c|}{ Male (n:3) } \\
\cline { 3 - 5 } & & Min. & Max. & Av. \\
\hline $\mathrm{HL}$ & 0.32 & 0.31 & 0.32 & 0.32 \\
$\mathrm{HW}$ & 0.38 & 0.36 & 0.39 & 0.37 \\
$\mathrm{HI}$ & 0.84 & 0.83 & 0.94 & 0.88 \\
$\mathrm{TL}$ & 0.37 & 0.33 & 0.36 & 0.34 \\
$\mathrm{TW}$ & 0.39 & 0.31 & 0.34 & 0.32 \\
$\mathrm{AL}$ & 0.81 & 0.59 & 0.80 & 0.70 \\
$\mathrm{AW}$ & 0.53 & 0.40 & 0.42 & 0.41 \\
Tot L & 1.43 & 1.17 & 1.45 & 1.31 \\
\hline
\end{tabular}

Abbreviations for measurements are: HL: Head Length; HW: Head Width in temples; HI: Head Index; TL: Thoracic Length; TW: Thoracic Width; AL: Abdominal Length; AW: Abdominal Width; Tot L: Total Length

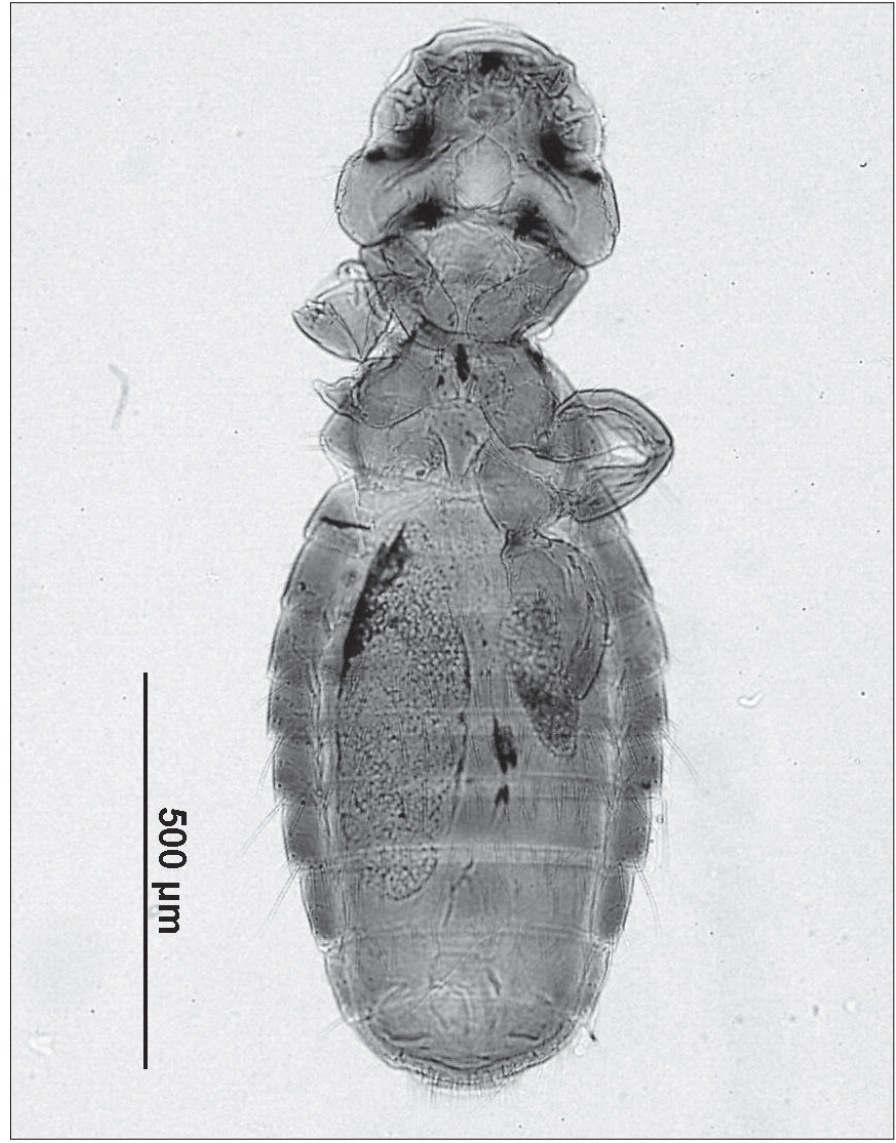

Figure 3. Afrimenopon waar, female in ventral view, original

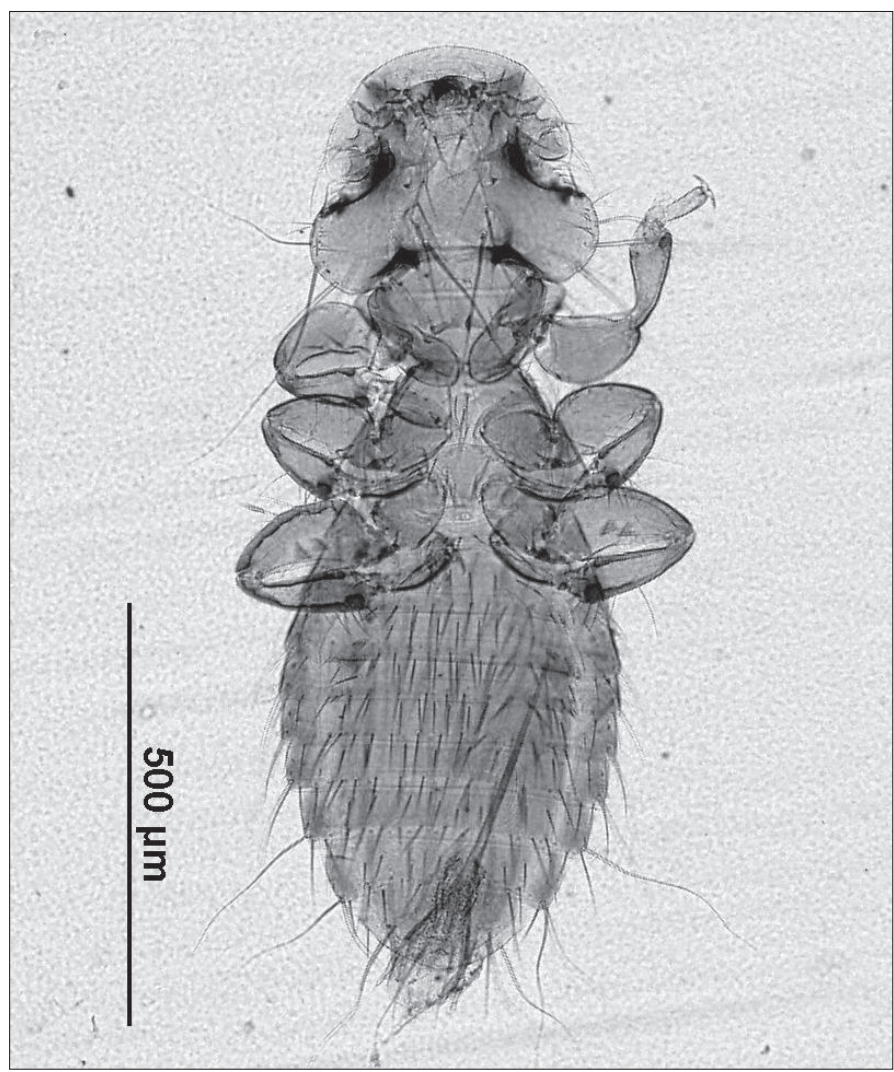

Figure 4. Afrimenopon waar, male in ventral view, original 


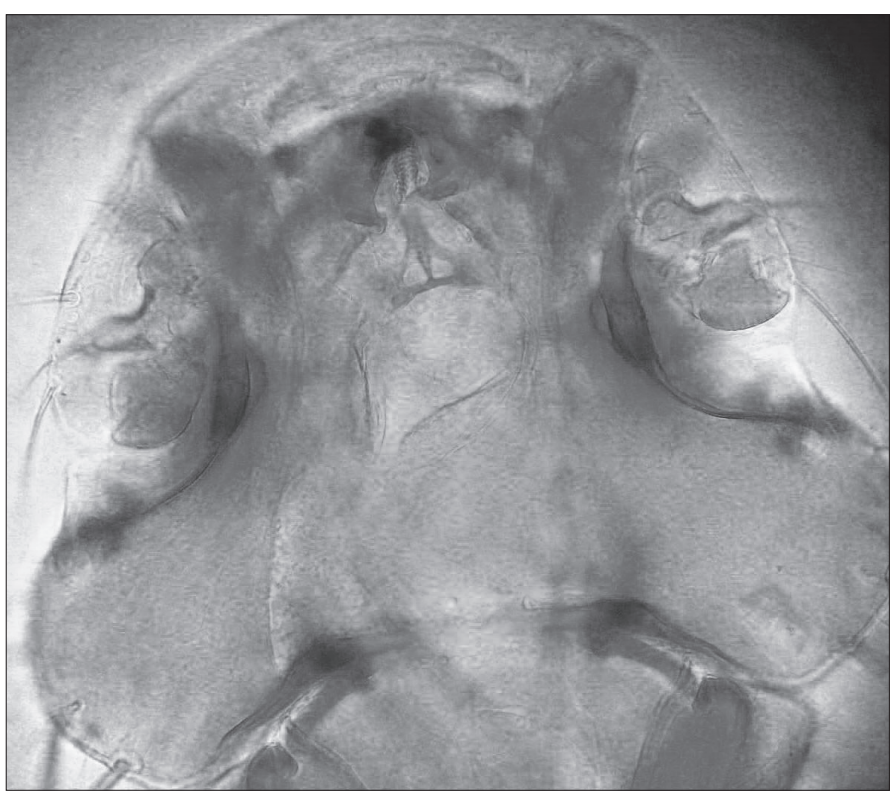

Figure 5. Afrimenopon waar, male head, original

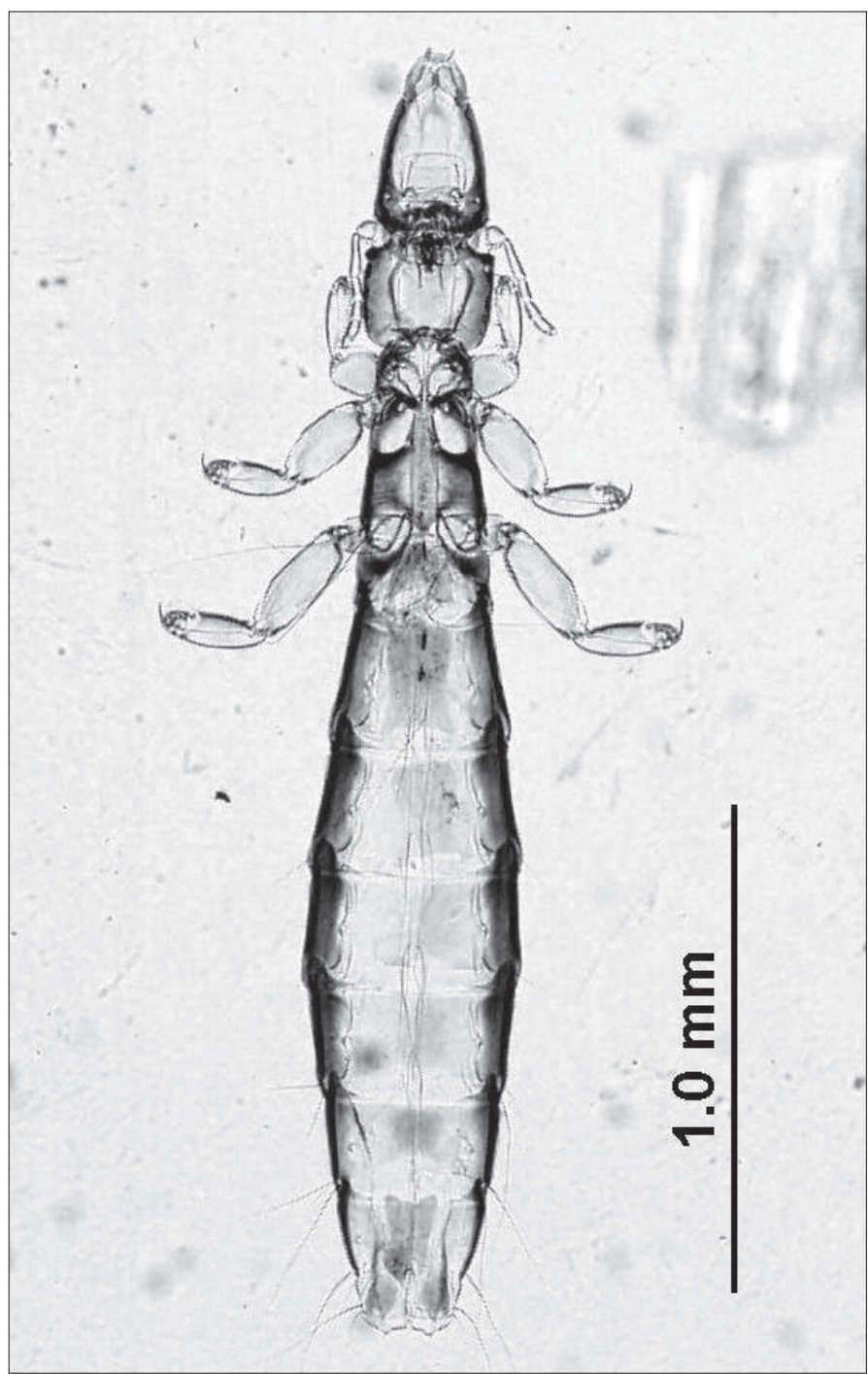

Figure 6. Columbicola bacillus, female, original

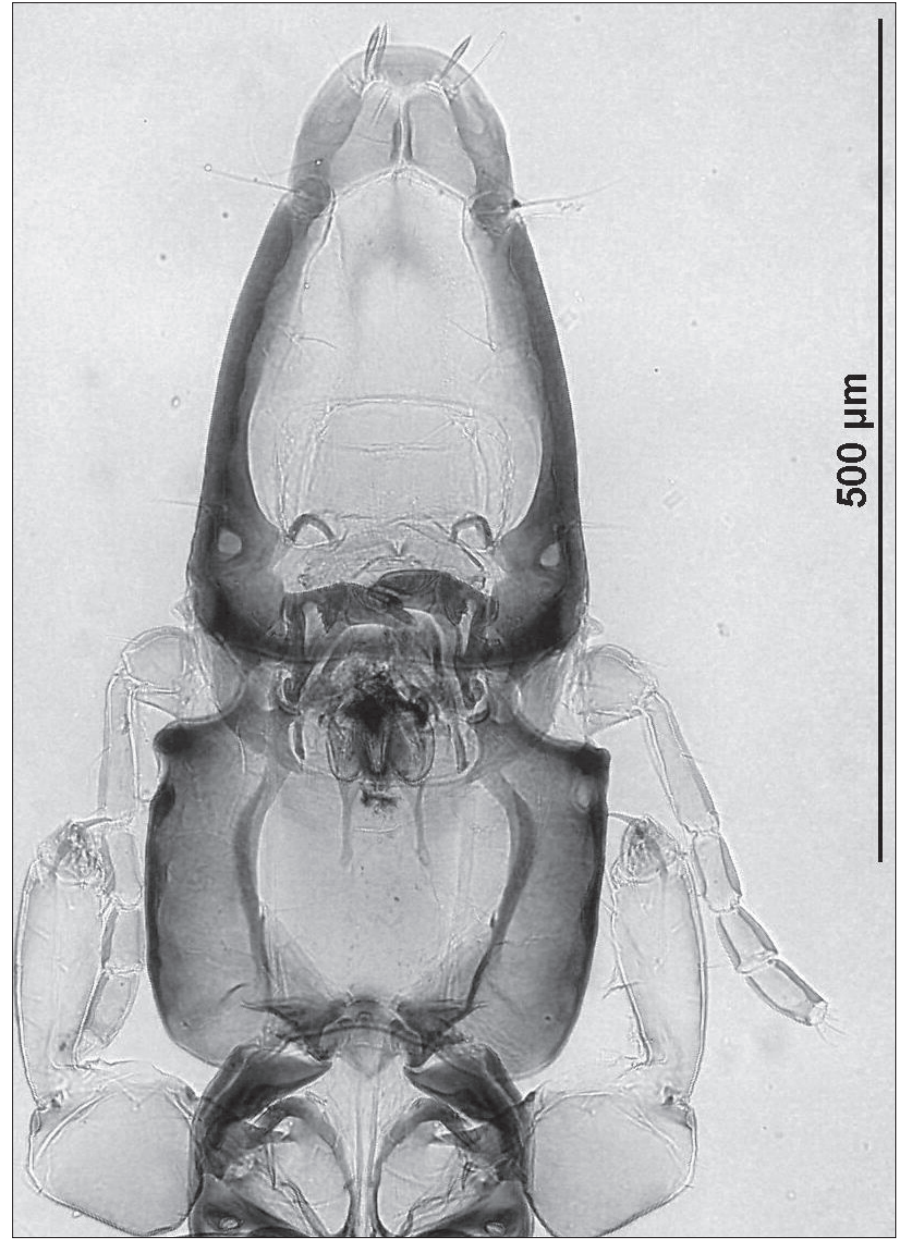

Figure 7. Columbicola bacillus, female head, original

$\mathrm{mm}$ wide (Fig. 7). Antenna with five segments; second is clearly longer than the others. Prothorax is slightly wider than long, while the pterothorax is longer than wide. There are very long two setae on each sides of the postero-lateral margin. Abdominal segments are weakly chitinized, pleural plates slender. A few setae are on all segments. There are four tergocentral setae, two anteriorly and close to the median line and the others close to the lateral margin and posteriorly on segments II-VIII. Ventral terminalia with 9 short setae are aligned along the sides of the median pigmented area (Fig. 8). Measurements of C.bacillus: HL 0,65; HW 0,28; HI 2,36; TL 0,42; TW 0,28; AL 1,73; AW 0,50; Total L 2,80.

\section{DISCUSSION}

A limited number of studies have been done on the Phthiraptera fauna of the birds in Turkey (1-15). In studies of the chewing lice on ducks (Anatidae) in Turkey $(2,5,11,19)$, Anaticola anseris (Linn, 1758) (=Esthiopterum anseris) was reported on domestic and wild geese (2, 19), Anaticola crassicornis (Scopoli, 1763) (=Esthiopterum crassicorne) and Holomenopon obscurum (Piaget, 1880) (=Menopon obscurum) was reported on various duck species (19). In Konya Zoo, some waterfowl (Anseriformes) such as the White-fronted Goose (Anser albifrons), Mallard (Anas platyrhynchos), Eurasian Wigeon (Anas penelope), Ruddy Shelduck (Tadorna ferruginea), Mute Swan (Cygnus olor) and Black Swan (Cygnus atratus) were examined, but no chewing lice 


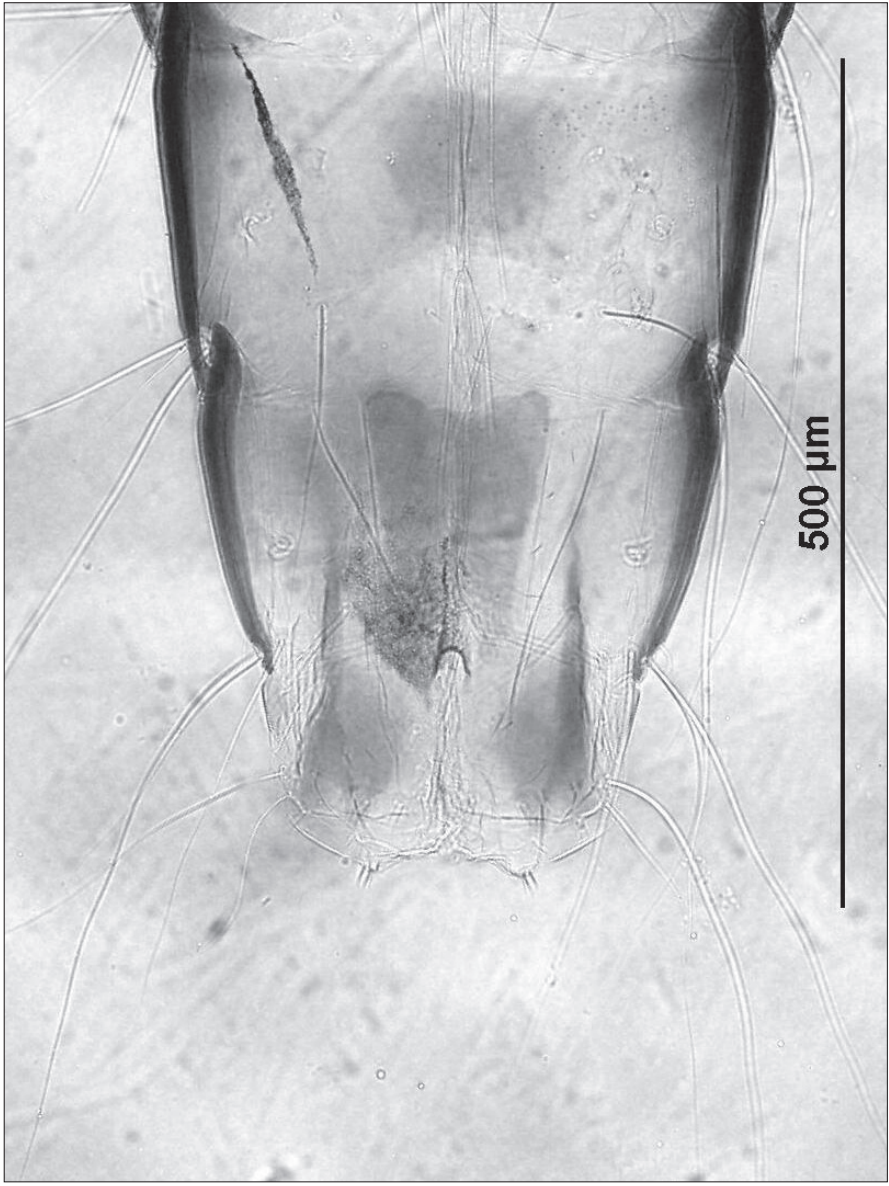

Figure 8. Columbicola bacillus, female, subgenital plate, original

were found (11). In this study, two specimens were obtained from the marbled duck (Marmaronetta angustirostris) and they were identified as Anatoecus icterodes (Nitzsch, 1818). The genus Anatoecus is a distinctive genus, characterised by the features of the head, chaetotaxy of the prothorax and other morphological characters. It has been reported on ducks, geese, and flamingos in the Afrotropical Region (20). Two lice species; A. dentatus and A. icterodes were found in the genus Anatoecus in Europe (21). Morphological characters of $A$. icterodes and/or $A$. dentatus were investigated in detail by some authors (20-26). This species is distinguished from $A$. dentatus (Scopoli, 1763) by the absence of the "effractor" in the male genitalia $(20,21,25)$. In this study, no "effractor" was observed in the genitalia of the male specimen of Anatoecus. Other characters of the male genitalia were very similar to the figures in Clay and Hopkins (1960, text-figures 59-61; Plate 2, Fig.39) (21). A. icterodes has been reported as a cosmopolitan species occurring on various host species in the family Anatidae (25-27), but had not been previously reported on the marbled duck. Therefore, the marbled duck is a new host for A. icterodes.

The genus Afrimenopon, with one known species, Afrimenopon waar (Eichler, 1947), is not common. A. waar was originally described from the rosy-faced lovebird (Agapornis roseicollis) and named Franciscoloa waar by Eichler (28-31). However, due to the inadequacy of the original description of Franciscoloa waar (Eichler, 1947), Price (28) established the genus Afrimenopon and included that species in the genus Afrimenopon. Sychra et al. (31) recorded this species on a captive budgerigar (Melopsittacus undulatus) and reported this species for the first time from Karachi, Pakistan. Formerly, Dik (5) investigated three budgerigars in Turkey, but did not find any louse specimen on the birds. Sychra et al. (31) reported that there were some slight differences between their specimen and Price's. In this study, almost all the morphological characters of our specimens were identical to those of Price (28) and Sychra et al. (31). However, almost all the dimensions examined in the study, except head length, were smaller than those examined by Price (28) and closer to those examined by Sychra et al. (31).

No study have been done on the chewing lice of Eurasian collared dove (Streptotelia decaocto) in Turkey while a few studies were done on the chewing lice of rock pigeon (Columba livia) in Turkey $(14,15,18,19)$. Columbicola bacillus has been recorded on Streptopelia decaocto worldwide (32-36). Clayton and Price (34) reported that $C$. bacillus is very similar to $C$. columbae, but differs from that species in having some measurements that are smaller, fewer setae (7-12) on the sub-genital plate in females and differences in some details of the male genitalia. Adams et al. (32) stated that $C$. bacillus differs from $C$. columbae due to greater head index, narrower dorsal anterior plate $(0,118-0,147$ $\mathrm{mm})$, and fewer setae on the sub-genital plate in females. In this study, only one female C. bacillus was collected from a Eurasian collared dove. The width of the dorsal anterior plate was 0,147 $\mathrm{mm}$, head index was 2.36, and ventral terminalia had 9 short setae aligned along the sides of the median pigmented area. These features are identical for $C$. bacillus.

\section{CONCLUSION}

Anatoecus icterodes, Afrimenopon waar, Columbicola bacillus, and the genera Anatoecus and Afrimenopon were recorded for the first time in Turkey. Also for the first time, the marbled duck was discovered to be a host for $A$. icterodes.

\section{Acknowledgements}

The author thanks Dr. R.C. Dalgleish for help about the confirmation of the identification of the marbled duck and comments for Anatoecus icterodes. I also thank Dr. Çağan Şekercioğlu for identification of the marbled duck.

\section{Conflict of Interest}

No conflict of interest was declared by the author.

\section{REFERENCES}

1. Aksin N. Elazığ yöresi yabani kekliklerde bulunan Mallophaga türleri. Turk J Vet Anim Sci 2003; 27: 559-65.

2. Aksin N. Elazığ yöresinde yabani kazlarda bit enfestasyonu. Turk J Vet. Anim Sci 2004; 28: 87-90.

3. Dik B. Mallophaga species on long-legged buzzards (Buteo rufinus) New records from Turkey. Türkiye Parazitol Derg. 2006; 30: 226-230.

4. Dik B. Türkiye'de, Çobanaldatanlarda (Caprimulgus europaeus L.)'da ilk Mulcticola hypoleucus (Denny, 1842) (Phthiraptera: Ischnocera) olgusu. Türkiye Parazitol Derg. 2009; 33: 212-4.

5. Dik B. Türkiye'deki Evcil ve Yabani Kanatılılarda Bulunan Çiğneyici Bit (Phthiraptera) Türleri. Türkiye Parazitol Derg. 2010; 34: 55-60.

6. Dik B, Aydenizöz Özkayhan M. Mallophaga species on longlegged buzzards (Buteo rufinus) in Turkey. Türkiye Parazitol Derg. 2007; 31: 298-301. 
7. Dik B, Uslu U. Konya'da Halkalı sülünlerde (Phasianus colchicus) Cuclotogaster heterographus (Mallophaga: Lipeuridae) enfestasyonu. Türkiye Parazitol Derg. 2006; 30: 125-7.

8. Dik B, Uslu U. Beyaz Leyleklerde (Ciconia ciconia Linnaeus, 1758) görülen Mallophaga (Insecta) türleri. Türkiye Parazitol Derg. 2006; 30: 220-5.

9. Dik B, Uslu U. Türkiye'de bir Puhu'da (Bubo bubo interpositus) Strigiphilus strigis (Mallophaga: Philopteridae). Türkiye Parazitol Derg, 2007; 31: 69-71.

10. Dik B, Uslu U. Türkiye'de, Beyaz Pelikanlarda (Pelecanus onocrotalus, Linneaus) görülen Mallophaga türleri. Türkiye Parazitol Derg, 2008; 32: 71-6.

11. Dik B, Uslu U. Konya Hayvanat Bahçesi'ndeki Kanatlı Hayvanlarda Görülen Çiğneyici Bit (Phthiraptera: Amblycera, Ischnocera) Türleri. Türkiye Parazitol Derg. 2009; 33: 43-9.

12. Dik B, Yamaç E. Türkiye'de bir Kara Akbaba'da (Aegypius monachus L.) ilk Colpocephalum trachelioti (Amblycera: Menoponidae). Türkiye Parazitol Derg. 2008; 32: 149-52.

13. Dik B., Uslu U., Derinbay Ekici Ö., Işık N. Türkiye'de, sığırcıklarda (Sturnus vulgaris, L.) görülen bit (Phthiraptera; Ischnocera, Amblycera) türleri. Türkiye Parazitol Derg. 2009; 33: 316-20.

14. Gıcık Y. Ankara ve çevresinde yaban güvercinlerde ektoparazitler. Kafkas Üniv Vet Fak Derg. 1999; 5: 71-4.

15. Gülanber A, Tüzer $E$, Çetinkaya, H. A survey on lice infestations of pigeons in İstanbul, Turkey. İstanbul Univ Vet Fak Derg. 2002; 28: 231-4.

16. Gülanber A, Kaya Ü, Vaassen EWAM, Yavuz E. Chewing-lice on longlegged Buzzard. Indian Vet J 2006; 83: 1238-9.

17. Güralp N, Mayılmayıl A. Samsun'da Sülünlerde (Phasianus colchicus) Görülen Sekal Trichostrongylose ile Mallophaga Enfeksiyonlarının Etken ve Sağaltımları. Ankara Üniv Vet Fak Derg, 1971; 18: 271-5.

18. Köroğlu E, Şimşek S. Elazığ yöresi güvercinlerinde (Columba livia) bulunan ektoparazitler ve yayılış oranları. F Ü Sağlık Bil Derg, 2001; 15: 195-8.

19. Merdivenci A. Türkiye'nin Entomolojik Coğrafyası. Türkiye'nin Parazitolojik Coğrafyası, Unat EK, Yaşarol Ş, Merdivenci A (Ed.), Ege Universitesi Matbaası, İzmir. p.1965: 114-52.

20. Ledger JA. The Arthropod Parasites of Vertebrates in Africa South of the Sahara. Volume IV. Phthiraptera (Insecta). Publications of the South African Institute for Medical Research. 1980; 56: 1-327.

21. Clay T, Hopkins GHE. The early literature on Mallophaga (Part IV, 1787-1818). Bull Br Mus nat Hist (Ent) 1960; 9: 1-61.
22. Cummings BF. Studies on the Anoplura and Mallophaga, being a report on the collection from mammals and birds in the Society's gardens. Part II. Proc Zool Soc Lond 1916; 643-93.

23. Eichler W. Mallophagen-Synopsis. VIII. Genus Anatoecus. Tijdschr v Entomologie, Deel 1946; 87: 74-6.

24. Eichler W. Anatoecus icterodes zlotorzycka nom.nov. Mallophagorum. Angew Parasitol, 1976; 17: 227-8.

25. Kéler Sv. Über die dualistiche differenzierung der Gattung Anatoecus Cummings (Mallophaga). Z Parasitenkde, 1960; 20: 207-316.

26. Séguy E. Faune de France, 43. Insectes Ectoparasites (Mallophages, Anoploures, Siphonaptéres). Paris, 1944: 684 pp.

27. Zlotorzycka J. Studien an den mitteleuropäischen Arten der Gattung Anatoecus Cumm. (Esthiopteridae, Mallophaga). Polskie Pismo Entomologiczne, 1970; 40: 7-67.

28. Price RD. A new Genus Afrimenopon for Franciscoloa waar Eichler (Mallophaga: Menoponidae). J Kansas Entomol Soc, 1970; 43: 372-7.

29. Price RD, Beer JR. A review of the genus Franciscoloa Conci (Mallophaga: Menoponidae). Pacific Insects, 1966; 8: 633-48.

30. Price RD, Hellenthal RA, Palma RL, Johnson KP, Clayton DH. The Chewing Lice: World checklist and biological overview. Illinois Natural History Survey Special Publication 2003; 24: 501.

31. Sychra O, Naz S, Rizvi SA. New record of Afrimenopon waar (Eichler) (Phthiraptera: Menoponidae) from budgerigar Melopsittacus undulatus (Psittaciformes: Psittacidae) from Karachi, Pakistan. Parasitol Res 2007; 101: 505-9.

32. Adams RJ, Price RD, Clayton DH. Taxonomic revision of Old World members of the feather louse genus Columbicola (Phthiraptera: Ischnocera), including description of eight new species. J Nat Hist 2005; 39: 3545-618.

33. Bush SE, Price RD, Clayton DH. Descriptions of eight new species of feather lice in the genus Columbicola (Phthiraptera: Philopteridae), with a comprehensive world checklist. J Parasitol 2009; 95: 286-94.

34. Clayton DH, Price RD. Taxonomy of New World Columbicola (Phthiraptera. Philopteridae) from the Columbiformes (Aves), with descriptions of five new species. Ann Entomol Soc Am 1999; 92: 675-85.

35. Eichler W. Die Mallophagengattung Columbicola Ewing. I. Teil: Die Arten der Gattung Columbicola. Sitz Gesell Naturforsch Freunde su Berlin 1942; 1941: 270-88.

36. Eichler W. Mallophagen-Synopsis. XXI. Genus Columbicola. Zool Anz 1952; 148: 346-56. 